Saudi Journal of Humanities and Social Sciences

Abbreviated Key Title: Saudi J Humanities Soc Sci

ISSN 2415-6256 (Print) | ISSN 2415-6248 (Online)

Scholars Middle East Publishers, Dubai, United Arab Emirates

Journal homepage: https://saudijournals.com/sjhss

Original Research Article

\title{
Public Infrastructure Provision Model, Challenges and Implications on Development in the Wum Municipality
}

Hycinth Ndze Ngong ${ }^{1 *}$, Lieugomg Medard ${ }^{2}$

${ }^{1}$ MSc. in Geography, University of Yaoundé 1, PhD Research Fellow, University of Bamenda, - P.O Box 39, Bambili Cameroon

${ }^{2}$ (PhD in Geography), Professor at the Higher Teachers' Training College-University of Yaounde 1

DOI: $10.36348 /$ sihss.2020.v05i04.005

| Received: 26.03.2020 | Accepted: 02.04.2020 | Published: 17.04.2020

*Corresponding author: Hycinth Ndze

Abstract

The model of public infrastructure provision in the domains of health, education and roads in the Wum Municipality is typical of Cameroonian society. It proves incommensurate with the growing knowledge endowment, technological advances and challenges in these domains. In this article, the authors examine the socio-economic challenges and impacts of the public infrastructure provision model. To achieve this objective, data were collected through direct observation, interviews and focus group discussions and complemented by documentary explorations, where related works in public institutions and online publications were consulted. A GPS Garmin model device was used to locate realised infrastructure and on-going projects. Photographs were taken using a smart phone, (Sony type) to enable the materialization of the observed phenomena. Google scholar was the principal research engine through which documents were obtained from the internet. The findings revealed a mixed scenario, precarious on one hand and promising in the other based on the indicators of progress and retrogression concomitantly observed. Using this model, results show that the provision of social facilities like schools, health centres benefited the population in terms of accessibility improvement. The same results revealed that this centralized state-led model of provision of livelihood facilities has created a societal problem - unsustainability of public infrastructure. This is noticed from the rapid degradation of recently executed projects. The phenomenon has further helped to accentuate poverty in the municipality. The paper concludes that project owners and contractors should put in place an efficient and autonomous control system to check the quality of material and technicians used in the process of public infrastructure provision.

Keywords: Contract, Development, Public, Infrastructure, Municipality, Wum.

Copyright @ 2020: This is an open-access article distributed under the terms of the Creative Commons Attribution license which permits unrestricted use, distribution, and reproduction in any medium for non-commercial use (NonCommercial, or CC-BY-NC) provided the original author and source are credited.

\section{INTRODUCTION}

The provision of public infrastructures in Cameroon and particularly in the Wum Municipalityis a prerequisite for livelihood sustenance and human development. This is possible through an efficient public procurement model and investment budget allocations. It is for this reason that a $25-30 \%$ GDP of India goes to public procurement [1]. In Cameroon, over $20 \%$ of the state budget much recently is used for public investment in infrastructures (Finance Law, 2014; Finance Law, 2015; Finance Law, 2016) [2-4]. The correlation between infrastructural investments and socio-economic welfare is significant $[5,6]$. Despite this concomitant growing necessity between investment in roads, schools, health centres and market infrastructure, challenges surface, Dominguez et al., [7]. In related literature, economic growth was identified as a key priority under the African Union's Strategic Plan for 2009-2012 [8], which aimed to encourage and help provide infrastructure funding to member states. Sachs et al., [9] and Collier [10], note the general importance of public infrastructure particularly in the areas of health and education. Public infrastructural provision continues to be the base of livelihoods and human capital development in the municipality in which over $73 \%$ of the population are farmers [11].

In the Wum Municipality, the potentials in terms of natural resources, that is to say; construction material such as sand, stones, wood, man power and know-how in both designing and construction is abundant. Moreover, the yearly allocation of financial resources for infrastructural projects is not critically low during the last decade. Furthermore, the Municipality produces qualified technicians every year across the technical vocational training schools in Cameroon. In spite of these endowments, the fast dilapidation of 
newly constructed infrastructure is a common characteristic observed in the sampled areas of Municipality. This ranges from classrooms, health centres, roads and even agricultural projects. Within the period between 1985-2017, infrastructural investments have undergone rapid depreciation in infrastructure quality manifested in the form of cracks on school building, potholes on newly rehabilitated roads, just to name but this. This phenomenon has impeded sustained social wellbeing in the municipality. From the low agricultural productivity as a result of poor farm-tomarket roads to the high transportation cost imposed on the population. Worst of all is the bad nature of the National road linking the municipality to the Regional Capital of the North West-Bamenda. The appointment of administrative authorities over the years has not helped to coordinate development projects efficiently in the area. Moreover, the untimely closure of the Wum Area Development Authority which was a local economic booster aggravated the infrastructure poverty situation [12]. This is evidenced by Canute A [13] who showed that the presence of Upper Noun Valley Development Authority (UNVDA) in the Ndop area contributes to local infrastructural development. All the development literature shows a positive correlation between infrastructure and economic growth trends.

\section{METHODOLOGY}

\section{Sampling Design, Method, Study Area and Data Analysis \\ Sampling Design}

The technique used to select the sample population was a simple random sample technique. This technique gave way for the selection of 10 villages out of 19 and a total sample size of 114 households. The randomly selected villages included; Kesu, Naikom, Waindu, Bangwe, Bu, Zoghekwo, Zoghefu, Magha,
Ghiedze and Ngoh. It was because of their homogeneity.

\section{Data Collection Technique}

The use of Primary and secondary data gave an opportunity to correlate information conjointly obtained from various sources. Secondary data included published and unpublished documents from state universities, particularly the University of Yaounde I and II. On the other hand, primary data were collected using direct observation, interviews and focus group discussions with household heads in each of the 10 villages. Continuous observation of infrastructures were reported by our respondents as some were actually present from the time of delivery to the time of the research. In order to obtain information on the location of these infrastructures, a GPS Garmin was used and a Sony smartphone was also used to take photographs.

\section{Presentation of Area}

The Wum municipality is located in Menchum Division of the North West region of Cameroon. It is a municipality that was carved out into Sub-Divisions from the former Wum Area Council in 1993 and is controlled by the Wum council. The municipality is situated between latitude $6^{\circ} \mathrm{N}$, and $7^{\circ} \mathrm{N}$ of the equator and longitude $9^{\circ} \mathrm{E}$ and $10^{\circ} \mathrm{E}$ of the Greenwich Meridian. It borders Fungom Sub Division to the north and the north east, Menchum Valley Sub Division to the west, Boyo Division to the south east, and Mezam Division to the south. It covers a surface area of $776.67 \mathrm{~km}$ square (Wum Council) with a total population of over 27.218 inhabitants BUCREP, 2005. Council sources in a diagnostic study carried out in 2010 puts the population of the Wum municipality at 68,484 inhabitants. The Wum Municipality is located some $85 \mathrm{~km}$ from Bamenda, the Regional administrative capital of the North West Region. Figure-1 shows the Wum Municipality in Menchum Division.

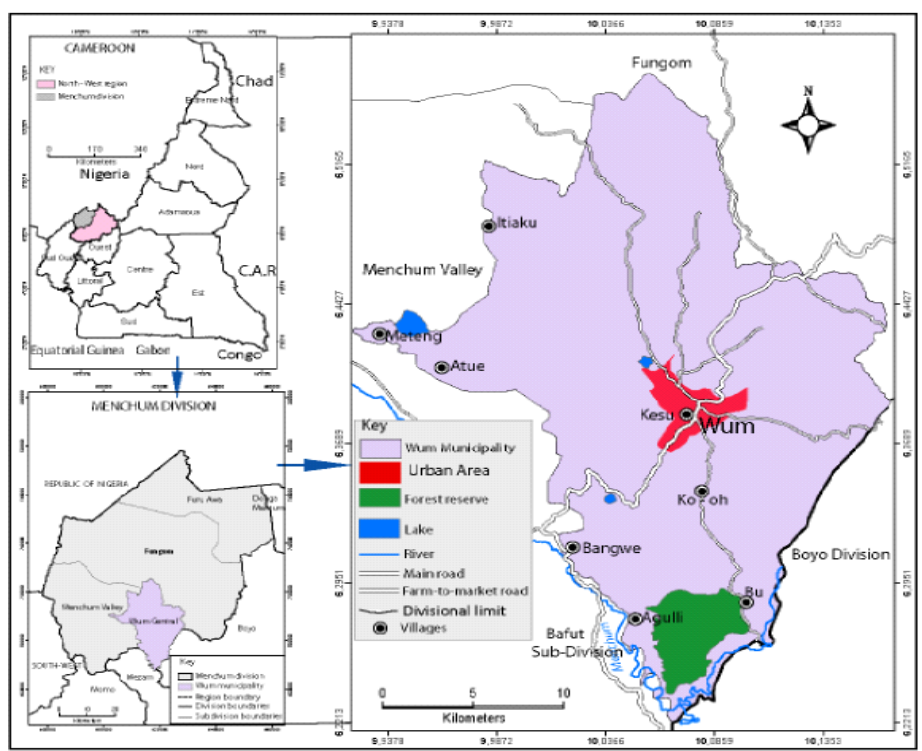

Fig-1: The location of the Wum Municipality in Menchum Division of the North West Region of Cameroon Source: Adapted from NIC database (2017) 


\section{DATA ANALYSIS}

Descriptive statistics were used and with the help of a statistical package for social sciences SPSS, analysis of covariance was possible and cross tabulation was done with the resultant tables imported into Microsoft Excel spread sheet for an automatic production of charts. It was through this process that ANOVA of the dependent and independent variables was matched to validate or invalidate the main hypothesis.

\section{PRESENTATION OF RESULTS AND DISCUSSION}

Data obtained from the field proves that despite the shortcomings of the model of infrastructure provision adopted by the central government and imposed upon the Wum Council, there has been improved human development in the municipality. However, this improvement in education and health care infrastructure provision is not complemented by an increase in economic infrastructural gains.

The public infrastructure provision model in the Wum Municipality

The government has been the main actor in the provision of public infrastructure in the Wum municipality. This role is seen principally in terms of allocating finances and providing technical expertise. It has been through a state direct engagement to a builddirect-transfer procurement system. This is the technical mutation that has transpired in the last three decades especially in the most apparent social domains like education and health. The construction and equipping of educational and health facilities were outsourced to individual contractors through the build and transfer system, under the lone technical supervision of the Ministry of Public Works. The contractors only hire and pay engineers who do the work and the facility is later transferred to the various competent government authorities for use by the population concerned.

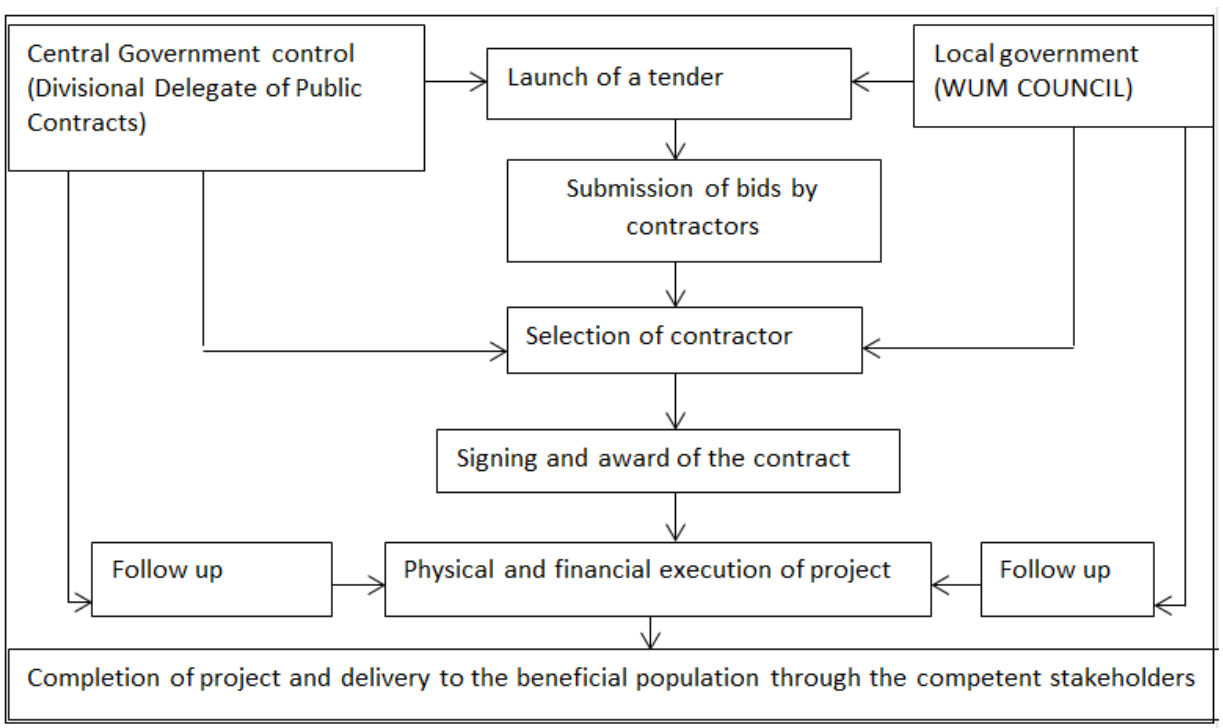

Fig-2: Top-down public infrastructure provision model in the Wum Municipality Source: Ngong Hycinth Ndze (2017)

\section{Public infrastructure provision Challenges}

Numerous obstacles are involved in the planning, execution and maintenance of public infrastructure. These are classified under internal and external challenges.

\section{Internal Challenges}

The internal causes are those that are more specific and are generated within the Wum municipality by routine factors that pull the development efforts backward.

\section{Use of unskilled technicians by contractors}

Qualified and competent technicians are expensive and thus many local contractors tend to avoid hiring skilful technicians. On the contrary, hiring of cheap labour is a common phenomenon in the realization of projects in the Wum municipality. When people are assigned to a task of which they are not competent to do, the result would be poor. In some cases, students in the technical school are allowed to perform duties which they are not competent or have not yet acquired the practical knowledge and skills in school. Even though this also contributes to training and more experience, it is a good approach but at the wrong time because only a nourished brain is supposed to be hired to ensure quality of work given their level of know-how. According to Edwin Tem, a civil engineer from the National Advanced School Public Works, "I for example, I'm a qualified and well trained engineer and carry out quality works that stand a test of time, but some contractors do not hire my services because they do not want to spend much money. I had an agreement with a contractor who promised to call me once a 
contract was given, but at the end I just heard that the contract was under execution supervised and worked by an inexperienced and incompetent engineer whose services were hired at a very cheap price."

\section{Bidding of contracts below the normal feasible execution amount}

Contracts are awarded to bidders that accept to execute the contract with resources lower than the legal amount of money stipulated. It is noted to be an acute hindrance to adequate and quality provision of infrastructure. The problems arise when the contracting authorities most often prefer to dictate their own price and to award a contract to a contractor who accepts to realise the project at a force-on price, agreed upon by 'them'.
In this system, when a tender is launched, bidding starts and if contractors $\mathrm{A}$ and $\mathrm{B}$ go for a tender, the likelihood that contractor $\mathrm{B}$ or $\mathrm{A}$ is accepted is not by competence, experience of executing similar contracts or timely delivery, it is rather by who accepts the lowest below the legal amount. A contractor executing a contract of 16000000 for 13500000 makes the contract duration longer that stipulated in the contract, the deliverable not resilient and project money is lost to corruption. In this circumstance, low quality material and unskilled technicians are used to minimize expenditure. According to one contractor interviewed in December 2015, "I refused a contract award because the money dictated to me could not realise the project and since I was guided by my conscience, I had to turn down the contract because the structure would have been a total mess if I accepted to realise it".

Table-1: Bidding for the construction of a $16000000 \mathrm{CFA}$ francs classrooms

\begin{tabular}{|l|l|l|}
\hline Construction Enterprises & Tendering board decision & Contractor's proposal \\
\hline Ets Wallang & 13500000 & 16000000 \\
\hline Ets Kum Robert & 13500000 & 15500000 \\
\hline Ets Mosco \& Sons & 13500000 & 15000000 \\
\hline Ets Fetaco & 13500000 & 14500000 \\
\hline Ets Memocam & 13500000 & 14000000 \\
\hline Ets Damcam & 13500000 & 13500000 \\
\hline Ets Damcam & Tendering Board & Consensus amount \\
\hline 13500000 & 13500000 & 13500000 \\
\hline
\end{tabular}

Source: Data generated from Field work, (Nov. 2017)

As seen on Table-1, this is a circumstance whereby state resources have been lost to the detriment of the general public, the government and the state. As seen on table 1, 2.500000 million has been lost as demonstrated by the model table. This is an example of what happens on the field. This phenomenon has existed for many years without any sustainable solution to it.

\section{External Challenges \\ Conflict of Interest amongst the Political Elite}

Conflicts often arise due to the differences in the political aspiration of the elite and more particularly the regional political elite. Conflicts of interest here are seen in the following perspectives; an elite who fails to lobby or facilitate the follow up and realisation of a project for the good of the population simply because the council executive or the entire constituency is controlled by a party in which he/she is not partisan. Going further, economic projects have been abandoned due to rivalry over the management of financial resources. "Some heavy equipment intended for the development of the former MIDENO project was mismanaged and we do not know how and where the machinery ended", (field work, 2016). The administrative system also makes it favourable for such conflicts. By law, the Senior Divisional Officer has the supervisory power thus control over every development project. This is a reliable source of conflict between the executive power and the locally elected authorities. This is the origin of the failure of many public social infrastructural and economic projects. For example, the closure of MIDENO in Wum, a project meant to continue the WADA project and the operational lapses observed with DMIRD resulted from this dilemma.

\section{Change in the governance system in the 1980s}

The governance system before 1980 was based on trust and verification. The hierarchy trusted their subordinates but verified their actions when and wherever it was necessary for the benefit of the citizens. After 1986, good governance and institutions became increasingly weaker, an informal "laiser-faire-laiseraller" policy systematically gained grounds in the daily affairs of the governing class. This factor helped to amplify the problems created by the economic crisis and the structural adjustment programmes. According to Adam Szirmai [14], strong shocks combined with weak institutions and policies may have disastrous effects and put an economy on a downward growth trajectory. Rapney J [15] articulated that "Structural adjustments were less effective in the poorest countries like in Central African Nations, those most in need of rapid change, it was, and in some places actually did more harm than good". People began practising the embezzlement of state funds and were not being punished because the concern was more of protecting political power than ensuring accountability in the management of public affairs. 
According to Sandbrook [16], Bratton and Van de Walle [17], "where the legitimacy of state institutions and the nation-state is weak, the stage is set for the emergence of states which rule on behalf of specific ethnic groups or class interests. In such settings, state economic policy is almost exclusively aimed at maintaining the power of the ruling group or class, at the expense of other segments of society" This situation led to the massive depletion of state financial resources by people who were entrusted to manage. The phenomenon became a habit and infiltrated into the middle class where bad practices began in the domains of public contracts, treatment of files and management of projects within the public infrastructure provision chain.

\section{Impacts of public infrastructure provision}

The effect of public infrastructure provision model used in the Wum Central Sub-Division is both positive and negative as examined below.

\section{Positive Impacts}

These impacts are those which have contributed significantly to the welfare of the people.

\section{Secondary Educational Enhancement}

New infrastructures have been provided such as new classrooms, laboratories, workshops, toilets, and computer laboratories. The advantages of these facilities are multi-dimensional and the importance of each dimension is seen on the results produced. At the individual level, the benefits are as follows: In the areas where secondary schools did not formerly exist, students had to trek very long distances in order to have access to secondary education. Secondary schools are decentralized which makes it easy for every child to continue school after primary education. Formerly, Government High School and Government Technical High School Wum and later on Government Bilingual High School Wum received students from all the rural part of the municipality and even beyond. Students in $\mathrm{Bu}$, Upkwa and Bangwe villages no longer by obligation go to Wum for secondary enrolment due to the creation of new schools and provision of classrooms.

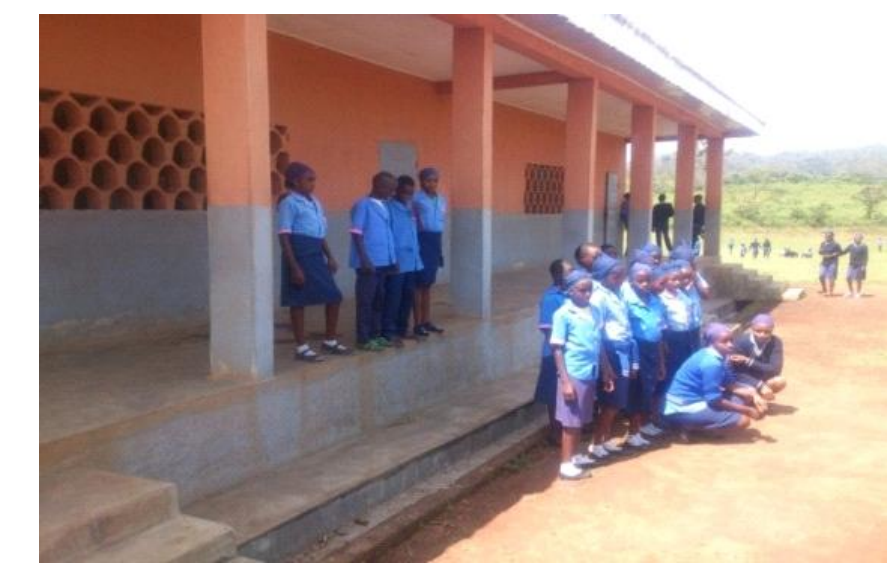

Photo-1: Increase enrolment of Fulani girls in secondary education GSS Upkwa Source: Field work (2017)

The parents of these Fulani girls due to cultural reasons did not send their children to secondary schools in the urban area of Wum. The creation of this infrastructure was a great relief for these parents and an opportunity for these young girls to increase their number of years in school. Up to $55.5 \%$ of students in G.S.S Upkwa are girls which makes the number more than the boys who went to Wum before this facility was provided in 2010, (field work 2015).

Furthermore, the parents especially those of the rural parts of the municipality like $\mathrm{Bu}$, Bangwe, and Upkwa, have benefited from the new infrastructural projects such as classrooms and toilets. For example, before $2011,99.2 \%$ of primary school pupils of G.S Upkwa especially the female folk did not continue school due principally to the absence of a secondary school (2015 field work). As a result of the creation of a secondary school at Upkwa which is also a resettlement camp for the lake Nyos victims, $100 \%$ of the pupils completing primary school continue secondary school at Government Secondary School Upkwa. In 2010, Government School Upkwa scored a $100 \%$ in the First School Leaving Certificate examination and no female pupil entered into form one, (field work, 2016). In 2015, more than $95 \%$ of the class six pupils of Government School Upkwa continued schooling in G.S.S Upkwa. To Mr. Moussa, the Secretary General of the Upkwa Community, "many children in this community had not been attending secondary school until the school was created and went operational in 2010/2011 academic year. We are really happy especially now that our female children can attend secondary school and be further emancipated". 


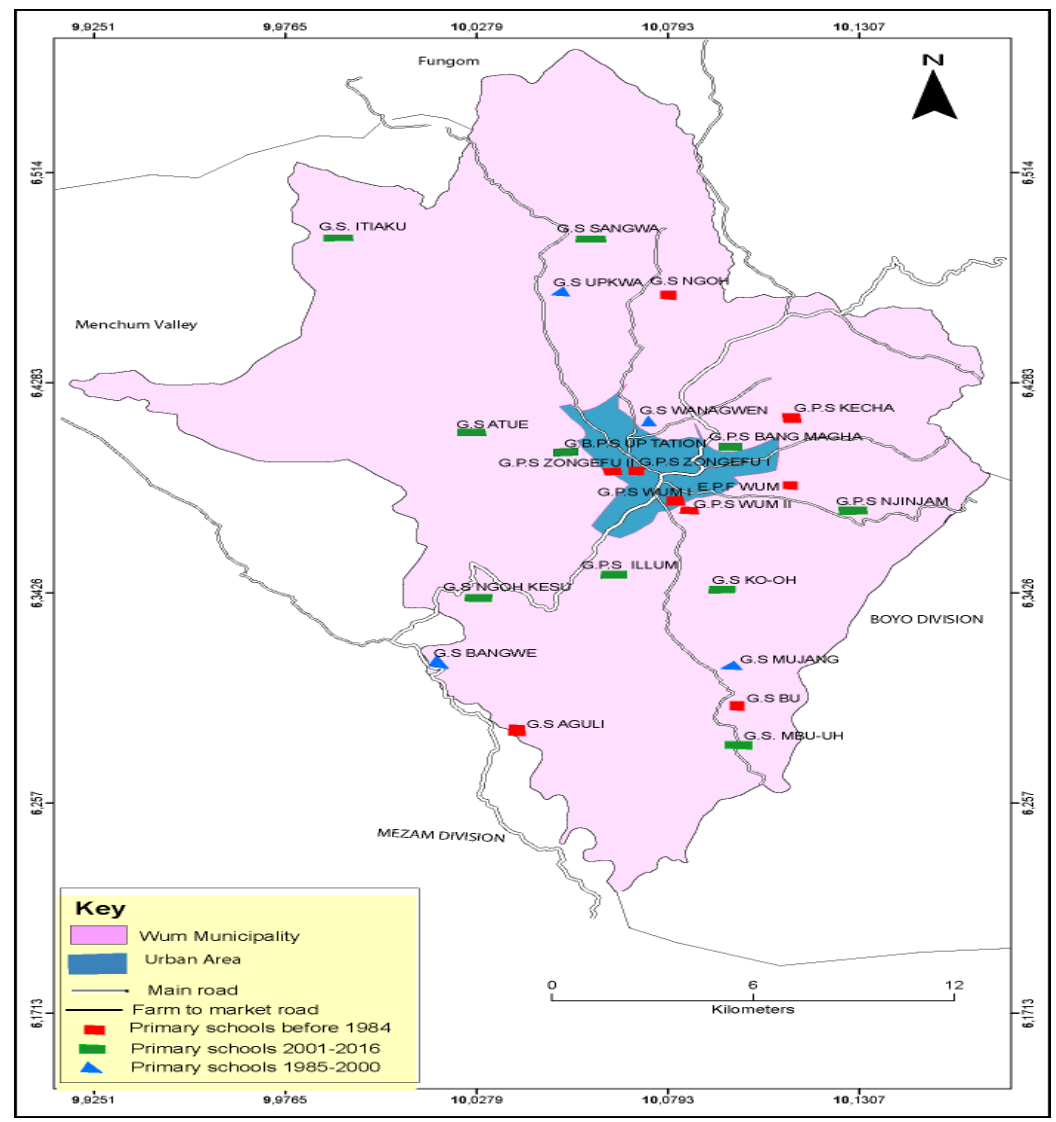

Fig-3: Spatio-temporal increase in primary schools in the municipality

Source: Field work (2017)

\section{Improvement in the healthcare system}

Health care infrastructures in this study refer to hospitals, health centres, and to a lesser extent the mortuary. The infrastructures provided do not only benefit the population directly in ensuring their health seen from the number of internal consultations, but also sensitization campaigns. These infrastructures have largely contributed to enhance the entire health system in particular by increasing access to health care services. The extension of health infrastructures into the villages of Kesu, Upkwa - Waindo, and $\mathrm{Bu}$; including the Wum District Hospital (W.D.H), has resulted to an improvement of the health of the population. Many people are now able to access health facilities as seen on Figure 4 and 5. For example, the Upkwa Integrated Health Centre (U.I.H.C) receives an average of 5 patients a day and this number goes up to 12 in the peak of dry and rainy seasons, that is January and August) when the areas experience extreme weather conditions accompanied by numerous air and water borne diseases.

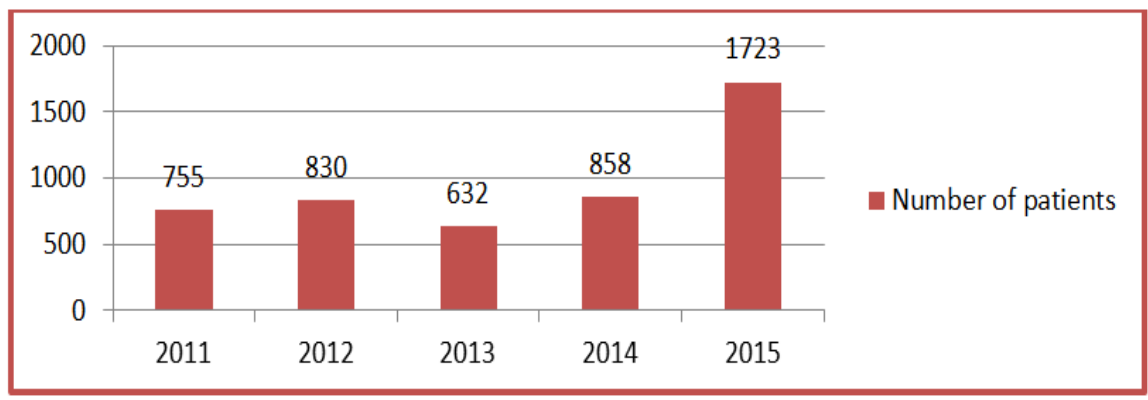

Fig-4: Consultation in the Wum Urban Integrated Health Centre 2011 - 2016

Source: Wum U.I.H.C, (2017)

Figure-4 shows a mark increase in the number of people seeking health services from 2011 to 2016 in the newly opened Urban Integrated Health Centre (UIHC). This increase has contributed in the reduction of patient- nurse ratio at the Wum District Hospital. Concomitantly, there has been a steady increase in the number of patients in the W.D.H in recent years as seen on figure-5 below. This increase is due mostly to water borne diseases especially in the dry season according to the hospital nurse. The drop in the number of patients in 2012 was as a result of the opening of the new U.I.H.C at Kesu. 


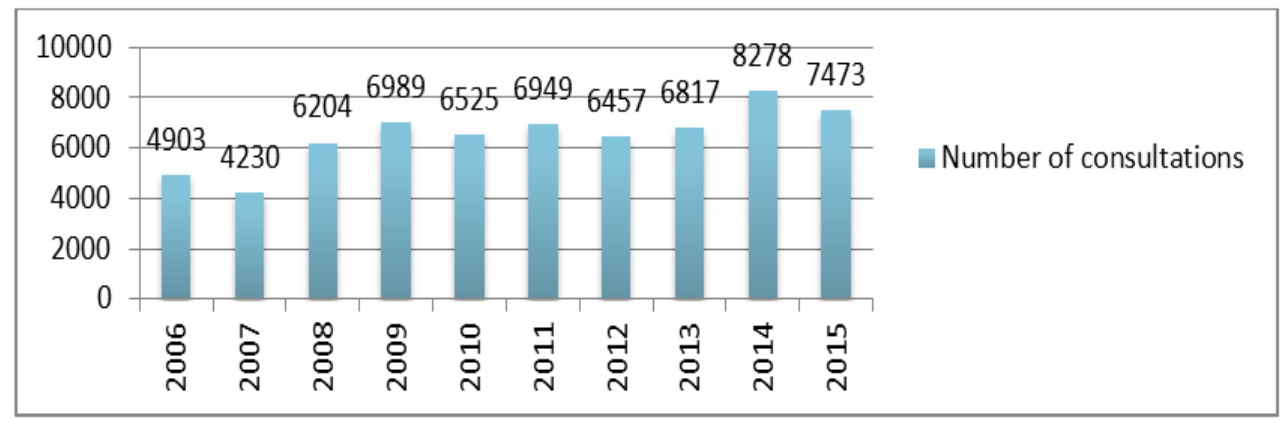

Fig-5: Consultations in the Wum district hospital (WDH) from 2006 - 2015

Source: WDH, (2017)

The illustrations in Figures 4 and 5 show the benefits of the health infrastructure projects realized in the municipality. The number of patients attended to by the medical personnel proves that the people are benefitting from the infrastructure and related services provided by the Wum District Hospital, the Wum Urban Integrated Health Centre, the Upkwa Integrated Health Centre, and the $\mathrm{Bu}$ Integrated Health Centre. There was a drop from 2014 to 2015 due to the creation of the Wum integrated health centre and the Upkwa I.H.C. In a nutshell, from 2006 to 2015 , the health units have received a total number of 69900 patients.

\section{The employability of the population}

This study begins in 1980 and WADA iswas abandoned in 1989, thus it covers a period of nine years of the existence of WADA. The positive impacts are therefore those impacts felt by the population during the functioning of the project up to 1990. This is the reason why it has been integrated in this study. This industrial enterprise began as an agricultural training scheme in 1965 and was finally given a bigger status by a presidential decree No $73 / 23^{\text {rd }}$ January 1973 , which was unfortunately closed in 1989 . The general objective of this project was made by the German - Cameroon Technical Assistance which was to assist in the socioeconomic development of the rural population of the former Menchum. According to Dzenyagha Awah [12], A. Vincent [18], WADA had carpentry and blacksmithing industries, undertook building projects in the construction industry, highly mechanized farming was enhanced, produced maize, rice, guavas, cheese in greater quantities, and most importantly a butter factory at "three corners" Wum. This factory increased dairy production among the cattle owners and attracted the consumption of the products in larger quantities. Furthermore, PAFSAT was operational by 1989 and before the abandonment of the WADA project, PAFSAT had already impacted the population by improving on the adapted animal traction system of farming.

Apart from these services, WADA also ran practical training and helped to standardize the technical knowledge and level of farmers and farm to market roads were opened, These benefits were meant to be sustainable for the growth of the Cameroonian economy in general and the Wum municipality in particular according to the cooperation agreement made in November 1980 which identified a sustainable rural development project to be under WADA. Dzenyagha Awah [12]. From this, many people had employment from WADA due to the value added activities, about 234 permanent staff, and other temporal employees, A. Vincent [18]. WADA also constructed houses for workers, and constantly rehabilitated roads especially farm to market roads. All these benefits were before the 1990s, because just the handing over of the project to the Cameroon government in 1982, mismanagement began and the structure collapsed and was abandoned without achieving the intended goals of poverty alleviation and sustainable enhancement of well-being.

\section{Positive impacts of good road infrastructures}

The people of the Wum municipality greatly benefitted from the rehabilitation of the Wum Bamenda road in the early 2000s up to 2005. During this period, transport from the municipality to other areas especially to Bamenda was cheap. Below is an expression of the feelings of some inhabitants of Wum in December 2015. A driver from the Menchum Professional Drivers' Union explained "I have been a driver on the Wum - Bamenda road since 1998, and when the road was rehabilitated in 2002, transport to Bamenda was fluid and cheap. I used to carry passengers to Bamenda for 800 FRS because I worked at Guarantee Express Com. Ltd. Other agencies carried people to Bamenda for 1000 FRS. That was relatively better as compared to the present situation in 2015". Adding to this, a woman at the Wum municipal market also explained how she used to have quick turnovers when the road was good just after the rehabilitation. "Between 2003 and 2007, I recorded the highest benefits since I started doing "bayam sellam". I deal with fresh vegetables, buying from the farmers of the neighbouring villages of Wum and sending to Douala through the Vatican or Guarantee public agencies in due to the good roads at that time.

In this same light, $95.4 \%$ of households were positively impressed that public projects are visible in the municipality though of very low quality especially in the road domain while just $4.6 \%$ disagreed that they did not benefit from social projects especially the 
Bamenda-Wum road in the early 2000s. Similarly, $95.5 \%$ of households strongly agreed that they greatly benefited from the classrooms and health units.

The second category of roads that have impacted on the population is the farm to market roads of the municipality. Farm to market roads only greatly benefit the population just after the rehabilitation has been completed and when the rainy season comes, it is just business as usual. Most of the farms to market roads are motorable roads like the road to Mbinjam, the road to Upkwa, the road to Kecha, the road to Atue, the road to $\mathrm{Bu}$, the road to Aguli, and the road to Ngoh opened by former Wum Area Development Authority. The level of productivity especially at Kecha is encouraged by accessibility and the rate of food crop damage is reduced.

\section{Negative impacts of the public infrastructure provision model \\ Increase in unemployment and waste of natural capital}

The neglect of WADA, a Project that raised and could continue to enhance the standards of living of the population through the provision of jobs and opening of opportunities by its multiplier effects suddenly created structural unemployment. The negative impacts of the absence are direct and indirect such as the unavailability of jobs, low disposable incomes in households, slow turnovers in businesses, and all these go to deteriorate the social welfare of the population. Based on this thought, $84.7 \%$ of household against $15.3 \%$ testify that there is a drop in household income due to the unsustainability of WADA, the major road into the municipality and other farm to market roads which easily get bad after rehabilitation. The minimum wage of an employee in WADA was
38.000CFA Francs a month. According to a former employee of WADA, "I'm now unable to have 23000 FRS after every effort put in a month. Everything now is very expensive and the cost of education too has increased" (field work, 2018). Very recently, 52.3\% of households earn less than 25000CFA Francs and 21.6\% earn between $25000-49000$ and only $5.4 \%$ of the population earn between 50000-99000CFA Francs. Further, $20.7 \%$ of the population agreed to have a monthly income of above 100000CFA Francs. This category were mostly civil servants and average business men.

The reason for this low income is principally due to the absence of a giant economic activity to change their conditions and improve on their purchasing power. Adding to the $50 \%$ is another $25 \%$ of households earning less than 50000 FRS CFA, making therefore a total of $79.7 \%$ of households with very limited financial backing.

The abandonment of WADA, increased unemployment in the Wum municipality to about $73 \%$ in the 1990s, reduced agricultural production and output by $71 \%$, reduced household disposable income by $65 \%$, and reduced the general economic activities to less than $37 \%$, \{comparative examination of 1976 - 1986 and $2000-2015$. (Field studies 2015) $\}$ This phenomenon is more acute in economic projects than in social projects.

Photo-2 below shows part of the road in the urban centre of the municipality rehabilitated in 2013 with funds from MINDUH but was observed to be in this state in 2015. According to the local population and the council sources in 2015 , this road was barely three years after works.

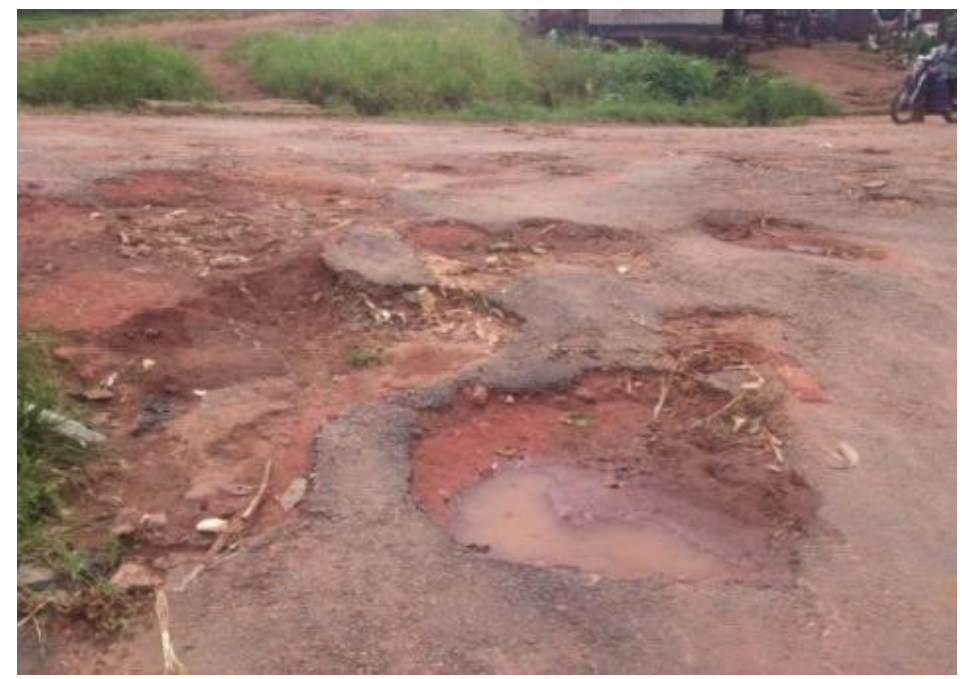

Photo-2: State of the council road section at Naikom Junction in 2015 Source: Field work (2015)

Furthermore, structures like health centres, classrooms and roads are constructed and after two to five years, some walls start depreciating, the roofs begin leaking. 


\section{CONCLUSION}

This study examined the public infrastructure provision model including its challenges and impacts on the livelihood of the population as the main objective. To achieve this objective, direct on-site observation, interviews and focus groups were the principal methods of obtaining primary data. From this, results evidenced that these social infrastructures have led to an increase in the educational enrolments, increase in the number of years spent in school as observed particularly in the Mbororo community of Upkwa. There is also an increase in the number of people with access to medical care due to the physical accessibility of the newly created health centres in Kesu and Upkwa. Nonetheless, the provision of infrastructures such as farm-to-market roads and the reform of the WADA project into DMID have not met the aspirations of the population over time due to reasons such as; - corruption and mismanagement, use of unskilled technicians, use of poor quality materials amongst others. Therefore the model opted by the government has also induced new societal problems such as the rise of unsustainable public infrastructures and rapid depreciation of infrastructure. It has over the past three decades, further culminated into a vicious cycle of economic hardship in the economy of Wum which needs rapid structural reforms like genuine transfer of political, technical and financial power to the Wum Council so as to revamp the rural economy.

\section{REFERENCES}

1. Arrowsmith, S., Treumer, S., Fejø, J., \& Jiang, L. (2010). Public procurement Regulation: An Introduction, Asia Inter-University Network for Teaching and Research in Public Procurement, 1023.

2. Law, S. H., \& Singh, N. (2014). Does too much finance harm economic growth?. Journal of Banking \& Finance, 41, 36-44.

3. Kang, M. S. (2015). The Brave New Word of Party Campaign Finance Law. Cornell L. Rev., 101, 531.

4. Fontana, D. (2016). The Geography of Campaign Finance Law. S. Cal. L. Rev., 90, 1247.
5. Thanapat, R. (2010). The Impact of Public Infrastructure Investment on Economic Growth in Thailand. International Economic Journal, 46-48.

6. Riverson, J. (1991). Rural roads in Sub-Saharan Africa. Lessons from World Bank experience. World Bank Technical Paper No 141, Africa Technical Department series. Washington D.C.

7. Domínguez-Ruvalcaba, H. (2011). Gloria Anzaldúa and the meaning of queer. In Bridging: How Gloria Anzaldúa's Life and Work Transformed Our Own (pp. 80-84). University of Texas Press.

8. Bilbao-Osorio, B., Dutta, S., \& Lanvin, B. (2013, April). The global information technology report 2013. In World Economic Forum (pp. 1-383).

9. Jeffrey, D. S., John, W. M. C., Schmidt-Traub, G., Margaret, K., Chandrika, B., Michael, F., \& Gordon, M. C. (2004). Ending Africa's Poverty Trap, Colombia, Columbia University, The millennium project, $44-51$.

10. Collier. (2006). Africa's economic Growth: Challenges and opportunities, Oxford University, 8-15

11. WUM COUNCIL \& PNDP. (2011). Wum Council Development Plan, 148-149,156-157.

12. Dzeyagha, A. (1993). Wum Area Development Authority (WADA), Unpublished Article, 1-9.

13. Canute, A. (2003). Development Authorities as an Agent of Development. The UNVDA in the Ndop area of Cameroon, 1970 -1999 in Nordie. Journal of African studies, 12:217-225.

14. Szirmai, A. (2008). Explaining success and failure in development. Maastricht University.

15. Rapley, J. (2007). Understanding Development: Theory and Practice in the Third World Third Edition, Lynne Rienner Publishers, 3-10.

16. Sandbrook, R. (1986). The state and economic stagnation in tropical Africa. World Development, 14(3), 319-332.

17. Bratton, M., \& Van de Walle, N. (1997). Democratic experiments in Africa: Regime transitions in comparative perspective. Cambridge university press.

18. Vincent, A. P., \& Yuen, D. A. (1988). Thermal attractor in chaotic convection with high-Prandtlnumber fluids. Physical Review A, 38(1), 328. 